\title{
FORTY-SIXTH SUPPLEMENT TO THE AMERICAN ORNITHOLOGISTS' UNION CHECK-LIST OF NORTH AMERICAN BIRDS
}

\author{
Author(s): Richard C. Banks, Carla Cicero, Jon L. Dunn, Andrew W. Kratter, Pamela C. Rasmussen, J. V.
} Remsen Jr., James D. Rising, and Douglas F. Stotz

Source: The Auk, 122(3):1026-1031.

Published By: The American Ornithologists' Union

DOI: http://dx.doi.org/10.1642/0004-8038(2005)122[1026:FSTTAO]2.0.CO;2

URL: http://www.bioone.org/doi/full/10.1642/0004-8038\%282005\%29122\%5B1026\%3AFSTTAO

$\% 5 \mathrm{D} 2.0 . \mathrm{CO} \% 3 \mathrm{~B} 2$

BioOne (www.bioone.org) is a nonprofit, online aggregation of core research in the biological, ecological, and environmental sciences. BioOne provides a sustainable online platform for over 170 journals and books published by nonprofit societies, associations, museums, institutions, and presses.

Your use of this PDF, the BioOne Web site, and all posted and associated content indicates your acceptance of BioOne's Terms of Use, available at www.bioone.org/page/terms_of_use.

Usage of BioOne content is strictly limited to personal, educational, and non-commercial use. Commercial inquiries or rights and permissions requests should be directed to the individual publisher as copyright holder. 


\title{
FORTY-SIXTH SUPPLEMENT TO THE AMERICAN ORNITHOLOGISTS' UNION CHECK-LIST OF NORTH AMERICAN BIRDS
}

\author{
Richard C. Banks, ${ }^{1,9,10}$ Carla Cicero, ${ }^{2}$ Jon L. Dunn, ${ }^{3}$ Andrew W. Kratter,${ }^{4}$ \\ Pamela C. Rasmussen, ${ }^{5}$ J. V. Remsen, Jr., ${ }^{6}$ James D. Rising, ${ }^{7}$ \\ and Douglas F. STOtz \\ ${ }^{1}$ U.S. Geological Survey, Patuxent Wildife Research Center, National Museum of Natural History, MRC-111, \\ P. O. Box 37012, Washington, DC 20013-7012, USA; \\ ${ }^{2}$ Museum of Vertebrate Zoology, 3101 Valley Life Sciences Building, University of California, Berkeley, \\ California 94720-3160, USA; \\ ${ }^{3} R R 2$, Box 52R, Bishop, California 93514, USA; \\ ${ }^{4}$ Florida Museum of Natural History, P. O. Box 117800, University of Florida, Gainesville, Florida 32611, USA; \\ ${ }^{5}$ Michigan State University Museum and Department of Zoology, West Circle Drive, East Lansing, \\ Michigan 48824-1045, USA; \\ ${ }^{6}$ Museum of Natural Science, Louisiana State University, Foster Hall 119, Baton Rouge, Louisiana 70803, USA; \\ ${ }^{7}$ Department of Zoology, Ramsay Wright Zoological Labs, University of Toronto, Toronto, Ontario, \\ M5S 3G5, Canada; and \\ ${ }^{8}$ Environmental and Conservation Programs, Field Museum of Natural History, 1400 S. Lake Shore Drive, \\ Chicago, Illinois 60605-2496, USA
}

This is the fifth Supplement since publication of the 7th edition of the Check-list of North American Birds (American Ornithologists' Union [AOU] 1998). It summarizes decisions made by the AOU's Committee on Classification and Nomenclature between 1 January and 31 December 2004. The Committee has continued to operate in the manner outlined in the 42nd Supplement (AOU 2000). Changes in this Supplement fall into the following categories: (1) two species replace others presently on the list because of splitting of extralimital forms (Leptotila plumbeiceps replaces L. rufaxilla and Hylocharis humboldtii replaces $H$. grayi); (2) one species is removed from the Appendix and added to the main list because of new distributional information (Circus aeruginosus); (3) one species is removed from the list because of its merger with another species on the list (Motacilla lugens); (4) one species is removed from the main list and placed in the Appendix (Acridotheres cristatellus); (4) two species are

\footnotetext{
${ }^{9}$ Authors are members of the Committee on Classification and Nomenclature of the American Ornithologists' Union, listed alphabetically after the Chairman.

${ }^{10}$ E-mail: banksr@si.edu
}

removed from the families in which they were previously treated and placed in incertae sedis categories (Donacobius atricapilla and Coereba flaveola), and one family is removed from the list (Coerebidae); (6) one genus is removed from the list (Mimodes) because of its merger with another on the list (Mimus), with the consequent change of the scientific name of one species; and (7) the distribution of one species is restricted because of the removal of an extralimital population now treated as distinct (Melanerpes chrysauchen). Further, one species is added to the list of birds known to occur in the United States (Tachycineta albilinea). A few recent references are added to statements of distribution. Minor corrections are made in several citations or notes.

There is one more deletion from the main list than additions to it, so the number of species in the main list becomes 2,037. Literature that provides the basis for the Committee's decisions is cited at the end of the Supplement, and citations not already in the Literature Cited of the 7th edition (with Supplements) become additions to it. An updated list of the bird species known from the AOU Check-list area may be accessed at http://www.aou.org/checklist/index.php3.

The following changes to the 7 th edition (page 
numbers refer thereto) and its Supplements result from the Committee's actions:

pp. xvii-liv. Insert the following names in the proper position as indicated by the text of this Supplement:

Circus aeruginosus Western Marsh Harrier Leptotila plumbeiceps Gray-headed Dove Hylocharis humboldtii Humboldt's Sapphire Mimus graysoni Socorro Mockingbird

Remove the following names: Leptotila rufaxilla Gray-fronted Dove Hylocharis grayi Blue-headed Sapphire Mimodes graysoni Socorro Mockingbird Acridotheres cristatellus Crested Myna Motacilla lugens Black-backed Wagtail Coerebidae

Insert the term Genus INCERTAE SEDIS above, and place an asterisk before, the following names (moving the entry for Donacobius to precede the family name Troglodytidae):

${ }^{*}$ Donacobius atricapilla Black-capped Donacobius

*Coereba flaveola Bananaquit

Remove the annotation $(\mathrm{H})$ :

\section{Gygis alba White Tern}

p. 60. In the citation of the original description of Branta sandvicensis, change the reference for Olson (1989) to 'Elepaio 49:49-51.

p. 93. Because of new distributional information, Circus aeruginosus is added to the Checklist. After the account for Circus cyaneus, insert the following new account:

Circus aeruginosus (Linnaeus). Western Marsh Harrier.

Falco aeruginosus Linnaeus, 1758, Syst. Nat. (ed. 10) 1:91. (Europa $=$ Sweden. $)$

Habitat. - Marshes and open grasslands.

Distribution.-Breeds in Europe and Asia from England to western Mongolia south to the Mediterranean, Caucasus, Iran, and northern Afghanistan, and winters in Africa south to Angola and the Transvaal, and from Iran through the Indian subcontinent south to Sri
Lanka and east to Myanmar; resident in northwestern Africa.

Casual to Madeira, and the Canary, Cape Verde, and Seychelles islands.

Accidental on Guadeloupe, 28 Nov. 2002-14 Apr. 2003 (Levesque and Malglaive 2004; photographs).

Notes. - The report of this species in Virginia (Shedd et al. 1998) that led to its inclusion in the Appendix (AOU 2000) is still considered unsatisfactory. Many authorities consider $C$. aeruginosus conspecific with C. spilonotus Kaup, 1847 [Eastern Marsh Harrier].

p. 108. In the account for Falco tinnunculus, add to Distribution: See Pranty et al. (2004) for additional detailed information.

p. 123. In the account for Numida meleagris, in the last line of Distribution, change Trinidad to Trindade.

p. 141. In the account for Burhinus bistriatus, add to first paragraph of Distribution: Recently reported breeding on Great Inagua, Bahamas (North American Birds 57:418, photo p. 432, 2003).

p. 207. The individual of Gygis alba photographed on Bermuda was originally identified as being of the candida group (Wingate and Watson 1974), and it was so listed in the 6th edition (AOU 1983). There is no evidence supporting its change to the alba group in the 7th edition (AOU 1998). Change the paragraph beginning "Accidental" in the distribution of this species by eliminating the mention of the alba group, and Tobago, which is out of the Check-list area.

p. 228. Genetic data (Johnson 2004) lead us to treat Leptotila plumbeiceps as a species distinct from L. rufaxilla, a treatment that follows traditional classifications (e.g. Meyer de Schauensee 1970, Goodwin 1983, Sibley and Monroe 1990, Baptista et al. 1997, Gibbs et al. 2001). The AOU (1983) considered plumbeiceps conspecific with L. rufaxilla, but did not provide or cite rationale. Remove the account of L. rufaxilla and insert the following in its place:

Leptotila plumbeiceps Sclater and Salvin. Grayheaded Dove 
Leptotila plumbeiceps Sclater and Salvin, 1868, Proc. Zool. Soc. London, p. 59 (Prov. Verae Pacis in rep. Guatemalensi, et Mexico $=$ Choctum, Vera Paz, Guatemala.)

Habitat.-Tropical Lowland Evergreen Forest Edge, Secondary Forest $(0-1,000 \mathrm{~m}$; Tropical and lower Subtropical zones).

Distribution.-As for the plumbeiceps and battyi groups in the account for L. rufaxilla.

Notes.-Groups: L. plumbeiceps [Grayheaded Dove]; L. battyi Rothschild, 1901 [Brown-backed Dove]. Formerly (AOU 1983, 1998) included in L. rufaxilla (Richard and Bernard, 1792) [Gray-fronted Dove] of South America but now treated as a separate species on the basis of genetic data (Johnson 2004) that supports the traditional classification (e.g. Goodwin 1983, Gibbs et al. 2001). The battyi group, which Wetmore (1968) recognized as a distinct species, has generally been included with plumbeiceps (e.g. Goodwin 1983, Ridgely and Gwynne 1989, Gibbs et al. 2001), which we continue to do here in the absence of published analyses. Reported vocal differences between L. plumbeiceps and L. battyi suggest that, with further study, they may merit status as separate species.

p. 295. Hylocharis humboldtii is separated from H. grayi, following Stiles (2003); see also Ridgely and Greenfield (2001). The two differ in habitat, elevation, coloration (especially males), and measurements (not only size but proportions), and they were treated as species until Peters (1945) treated them as conspecific without explanation. The population in the Check-list area is $H$. humboldtii, so the account for $H$. grayi is replaced by the following:

Hylocharis humboldtii (Bourcier and Mulsant). Humboldt's Sapphire

Trochilus humboldtii Bourcier and Mulsant, 1852, Ann. Sci. Phys. et Nat. Lyon (2) 4:142. (River Mira, Esmeraldas [Ecuador]; perhaps southwestern Colombia as suggested by Ridgely and Greenfield 2001:353.)

Habitat. - Mangroves and adjacent lowlands (Tropical Zone).

Distribution.-Resident along the Pacific coast from extreme southeastern Panama (near
Jaqué in southern Darién) to northern Ecuador (Esmeraldas).

Notes.-Formerly treated as conspecific with H. grayi (DeLattre and Bourcier, 1845) [Blue-headed Sapphire] of the Pacific foothills and drier valleys of the Andean Pacific slope in Colombia and northern Ecuador, but Stiles (2003) showed that differences in habitat, color of males, size, and proportions are consistent with treatment as separate species; see also Ridgely and Greenfield (2001).

p. 333-334. The South American Melanerpes pulcher is recognized as a species distinct from $M$. chrysauchen, following the treatment by Wetmore (1968) and Stiles and Skutch (1989), who considered the plumage differences to be comparable to species level differences in other Melanerpes. Authors who have treated them as conspecific (e.g. Peters 1948, Sibley and Monroe 1990, Winkler et al. 1995) have not provided a specific rationale for so doing.

Remove the phrase (chrysauchen group) and all mention of the pulcher group from the paragraph on Distribution. Replace the first sentence of the Notes with: Formerly included $M$. pulcher Sclater, 1870 [Beautiful Woodpecker] of the Magdalena Valley of Colombia, now treated as distinct following Wetmore (1968) and Stiles and Skutch (1989). Add M. pulcher Sclater, 1870 to the species in the presumed superspecies.

p. 457. Sykes et al. (2004) documented the first Mangrove Swallow (Tachycineta albilinea) in the United States. To the statement of distribution of that species, add a paragraph: Accidental in Florida (Viera Wetlands, Brevard County, 18-25 Nov. 2002; Sykes et al. 2004).

p. 469-470. In the account for Sitta pusilla, add to Distribution: See Renfrow (2003) for additional information.

p. 471. Genetic data (Barker 2004) show that Donacobius is neither a wren nor a mimid, as previously treated, but belongs in some Old World sylvioid group. Remove the account for Donacobius atricapilla from the family Troglodytidae and place it ahead of that family under a new centered heading Genus INCERTAE SEDIS. 
Replace the Notes under the genus Donacobius with the following: This enigmatic taxon was formerly treated in the Mimidae (Davis and Miller in Mayr and Greenway 1960) and then the Troglodytidae (AOU 1983, 1998), but recent genetic analysis indicates that it is closest to members of an Old World sylvioid assemblage (Barker 2004). Its proper placement is yet to be determined by a more complete taxonomic sampling.

p. 516-518. An analysis of mtDNA sequence data (Barber et al. 2004) shows that the species known as Mimodes graysoni is actually embedded within the genus Mimus and is most closely related to Mimus polyglottos and M. gilvus. This necessitates the following changes: Remove the heading for the genus Mimodes from p. 518; move the citation for Mimodes to p. 516, under the citation for Mimus; move the account for the species Mimus graysoni to a position following that of $M$. gilvus on p. 517; add to the Notes under M. graysoni: Formerly treated in the monotypic genus Mimodes, but now shown by genetic data (Barber et al. 2004) to be embedded in Mimus.

p. 524. Acridotheres cristatellus has become extirpated in North America (Self 2003), nearly a century after its introduction. Remove the species from the main list, and add an account for it in the Appendix (see p. 697, below).

p. 526-527. Reevaluation of the evidence for considering Motacilla lugens a species distinct from M. alba, of which it had long been considered a subspecies (AOU 1982, 1983), has led to its merger back into that species, in agreement with most recent treatments (e.g. Voelker 2002, Alström and Mild 2003). Incorporate the appropriate sections of the Distribution in the present $M$. lugens account into the account of M. alba, as the [lugens group], after the alba group. In the Notes for M. alba, insert: "M. lugens Gloger, 1829 [Black-backed Wagtail]" after the alba group and change the sentence following the listing of groups to read: Motacilla lugens was separated as a distinct species by AOU $(1982,1983,1998)$ and some Russian workers (Stepanyan 1978, Kistchinski 1980) on the basis of contact with supposedly only limited hybridization in areas of overlap in Ussuriland with $M$. a. leucopsis Nazarenko (1968) and in northern Kamchatka with M. a. ocularis (Kistchinski and Lobkov
1979). Most European authorities did not separate the forms as species, however. Alström and Mild (2003) suggested that the amount of hybridization had been underestimated, and they treated lugens as a subspecies of alba, a treatment also indicated by Voelker (2002) on the basis of genetic analysis.

p. 569. Two genetic data sets (Sato et al. 1999, Burns et al. 2002, 2003) have shown that the genus Coereba is embedded in a clade of "island" taxa, most of which were formerly classified as sparrows (Emberizidae/Emberizinae). Therefore, maintaining the family Coerebidae, as constituted solely by Coereba, is untenable. The familial placement of Coereba is yet to be determined. Remove the heading for the Family Coerebidae and replace it with the centered heading Genus INCERTAE SEDIS.

p. 691. In the citation for Buteo buteo, change the page number from 1 to 50 .

p. 697. Before the account for Acridotheres javanicus, insert the following account for $A$. cristatellus:

\section{Acridotheres cristatellus (Linnaeus). Crested Myna.}

Gracula cristatellus Linnaeus, 1758, Syst. Nat. (ed. 10) I: 109. Based on "The Chinese Starling or Blackbird" Edwards, Nat. Hist. Birds I: 19, pl. 19. (In Chinese.)

A population of this native of China and southeastern Asia was introduced and seemingly well established in southwestern British Columbia (Vancouver region) from the late 1800s until February 2003, when it was extirpated (Self 2003). Individuals from that population ranged to Vancouver Island (nesting attempted) and northwestern Washington. A bird seen in Portland, Oregon, in 1922 may have been from that population or may have escaped locally (Gabrielson and Jewett 1940, Marshall et al. 2003). Reports from Florida (Miami-Dade and Brevard counties) are based on escaped birds. Also reported in Puerto Rico, but status uncertain.

p. $705 \mathrm{ff}$. In the list of French names of North American Birds, make the following changes: 
Insert in the appropriate place in main list: Circus aeruginosus Busard des roseaux Leptotila plumbeiceps Colombe à calotte grise Hylocharis humboldtii Saphir de Humboldt Mimus graysoni Moqueur de Socorro

Delete the entries for the following: Leptotila rufaxilla

Hylocharis grayi

Mimodes graysoni

Motacilla lugens

COEREBIDAE

Circus aeruginosus Busard des roseaux (from Appendix portion of list, where added by AOU (2000)

Insert the term INCERTAE SEDIS above, and place an asterisk before, each of the following names (moving the name Troglodytidae to follow Donacobius and changing the name of the latter):

*Donacobius atricapilla Donacobe à miroir *Coereba flaveola

Move the entry for Acridotheres cristatellus from the main list to the Appendix.

The committee considered several other taxonomic changes, but did not make changes because of insufficient or conflicting information. Included were several proposals concerning generic and specific limits and relationships in the Parulidae. Action on these proposals awaits further genetic data from studies that include more complete coverage of the taxa involved.

\section{Acknowledgments}

Normand David serves as the Committee's authority for classical languages relative to scientific names, and Michel Gosselin serves as the authority for French names. We also thank D. D. Gibson, Sir C. Lever, J. O’Donahue, A. P. Peterson, and F. G. Stiles.

\section{Literature Cited}

Alström, P., And K. Mild. 2003. Pipits and Wagtails. Princeton University Press, Princeton, New Jersey.

American Ornithologists' Union. 1982. Thirty-fourth supplement to the American
Ornithologists' Union Check-list of North American Birds. Auk 99:1CC-16CC.

American Ornithologists' Union. 1983. Check-list of North American Birds, 6th ed. American Ornithologists' Union, Washington, D.C.

American Ornithologists' Union. 1998. Check-list of North American Birds, 7th ed. American Ornithologists' Union, Washington, D.C.

American Ornithologists' Union. 2000. Forty-second supplement to the American Ornithologists' Union Check-list of North American Birds. Auk 117:847-858.

Baptista, L. F., P. W. Trail, and H. M. Horblit. 1997. Family Columbidae (Pigeons and Doves). Pages 60-243 in Handbook of the Birds of the World, vol. 4: Sandgrouse to Cuckoos (J. del Hoyo, A. Elliott, and J. Sargatal, Eds.). Lynx Edicions, Barcelona, Spain.

Barber, B. R., J. E. Martinez-Gómez, and A. T. Peterson. 2004. Systematic position of the Socorro Mockingbird Mimodes graysoni. Journal of Avian Biology 35:195-198.

BARKer, F. K. 2004. Monophyly and relationships of wrens (Aves: Troglodytidae): A congruence analysis of heterogeneous mitochondrial and nuclear DNA sequence data. Molecular Phylogenetics and Evolution 32: 486-504.

Burns, K. J., S. J. Hackett, and N. K. Klein. 2002. Phylogenetic relationships and morphological diversity in Darwin's finches and their relatives. Evolution 56:1240-1252.

Burns, K. J., S. J. HACKETT, AND N. K. Klein. 2003. Phylogenetic relationships of Neotropical honeycreepers and the evolution of feeding morphology. Journal of Avian Biology 34: 360-370.

Gabrielson, I. N., and S. G. Jewett. 1940. Birds of Oregon. Oregon State College, Corvallis, Oregon.

Gibbs, D., E. Barnes, And J. Cox. 2001. Pigeons and Doves: A Guide to the Pigeons and Doves of the World. Yale University Press, New Haven, Connecticut.

Goodwin, D. 1983. Pigeons and Doves of the World, 3rd ed. Cornell University Press, Ithaca, New York.

Johnson, K. P. 2004. Deletion bias in avian introns over evolutionary timescales. Molecular Biology and Evolution 21:599-602. 
Kistchinski, A. A. 1980. [Birds of the Koryak Highlands.] Nauka, Moscow.

Kistchinski, A. A., ANd E. G. Lobkov. 1979. [Spatial relationships between some bird subspecies in the Beringian forest-tundra.] [Bulletin of Moscow Society of Naturalists, Biological Series] 84(5):11-23.

Levesque, A., And L. Malglaive. 2004. First documented record of Marsh Harrier for the West Indies and the New World. North American Birds 57:564-565. [2003 vol.]

Marshall, D. B., M. G. Hunter, and A. L. Contreras, Eds. 2003. Birds of Oregon: A General Reference. Oregon State University Press, Corvallis.

Mayr, E., and J. C. Greenway, Jr., Eds. 1960. Check-list of Birds of the World, vol. 9. Museum of Comparative Zoology, Cambridge, Massachusetts.

Meyer de Schauensee, R. 1970. A Guide to the Birds of South America. Livingston Publishing Company, Wynnewood, Pennsylvania.

Nazarenko, A. A. 1968. [On the character of interrelations of the two forms of Pied Wagtails.] (In Russian with English summary.) Problemy Evoliutsii 1:195-201.

Olson, S. L. 1989. David Douglas and the original description of the Hawaiian Goose. 'Elepaio 49:49-51.

Peters, J. L. 1945. Check-list of Birds of the World, vol. 5. Harvard University Press, Cambridge, Massachusetts.

Peters, J. L. 1948. Check-list of Birds of the World, vol. 6. Harvard University Press, Cambridge, Massachusetts.

Pranty, B., E. Kwater, H. Weatherman, and H. P. Robinson. 2004. Eurasian Kestrel in Florida: First record for the southeastern United States, with a review of its status in North America. North American Birds 58: 168-169.

Renfrow, F. 2003. Notes on vagrancy in Brownheaded Nuthatch, with attention to recent range expansion and long-term habitat changes. North American Birds 57:422-428.

Ridgely, R. S., And P. J. Greenfield. 2001. The Birds of Ecuador, vol. 1: Status, Distribution, and Taxonomy. Comstock Publishing Associates, Ithaca, New York.
Ridgely, R. S., And J. A. Gwynne, JR. 1989. A Guide to the Birds of Panama, with Costa Rica, Nicaragua, and Honduras, 2nd ed. Princeton University Press, Princeton, New Jersey.

Sato, A., C. O'nuigin, F. Figueroa, P. R. Grant, B. R. Grant, H. Tichy, and J. Klein. 1999. Phylogeny of Darwin's finches as revealed by mtDNA sequences. Proceedings of the National Academy of Sciences USA 96: 5101-5106.

SELF, B. 2003. Vancouver Crested Mynas gone. Winging It 15:7.

[Shedd, D. H., R. D. Gettinger, B. L. Shedd, And F. R. Sсотт.] 1998. First record of a Western Marsh Harrier (Circus aeruginosis) [sic] in Virginia. Raven 69:56.

Sibley, C. G., and B. L. Monroe, Jr. 1990. Distribution and Taxonomy of Birds of the World. Yale University Press, New Haven, Connecticut.

Stepanyan, L. 1978. [Composition and Distribution of the Avifauna of the Soviet Union-Passeriformes.] Nauka, Moscow.

Stiles, F. G. 2003. Notas taxonómicas sobre aves colombianas. I. El rango taxonómico de Hylocharis humboldtii (Trochilidae). Ornitología Colombiana 1:68-70.

Stiles, F. G., AND A. Sкutch. 1989. A Guide to the Birds of Costa Rica. Cornell University Press, Ithaca, New York.

Sykes, P. W., Jr., L. S. Atherton, M. Gardler, And J. H. Hintermister, V. 2004. The first Mangrove Swallow recorded in the United States. North American Birds 58:4-11.

Voelker, G. 2002. Systematics and historical biogeography of wagtails: Dispersal versus vicariance revisited. Condor 104:725-739.

Wetmore, A. 1968. The Birds of the Republic of Panamá, part 2. Smithsonian Miscellaneous Collections, vol. 150.

Wingate, D. B., and G. E. Watson. 1974. First North Atlantic record of the White Tern. Auk 91:614-617.

Winkler, H., D. A. Christie, and D. Nurney. 1995. Woodpeckers: A Guide to the Woodpeckers of the World. Houghton Mifflin, Boston, Massachusetts.

This Supplement is a publication of the American Ornithologists' Union. Copies (and earlier Supplements) are available for $\$ 3.00$ each from Buteo Books, 3130 Laurel Road, Shipman, Virginia 22971, USA. Buteo Books is the official sales outlet for publications of the AOU. 